UDC 338.2

DOI:10.15587/2313-8416.2015.47414

\title{
FRAMEWORK FOR MEASURING THE MANAGEMENT PERFORMANCES IN WESTERN BALKAN COUNTRIES; PROBLEMS, CONTROVERSIES AND SOLUTIONS
}

\section{(C) Sofija Adzic}

The basic objective of this paper is to obtain a coherent set of indicators for external analysis of the problems and processes of business development. The key finding is that the framework for external measurement of management performances should be put into operation of improving the competitiveness and increasing social responsibility

Keywords: Management, (Management) Performance measurement system, Holistic approach, Improving the competitiveness and social responsibility, Commercial and public development institutions

Основною метою даної роботи є отримання погодженого набору показників для зовнішнього аналізу проблем і процесів розвитку бізнесу. Зроблено основний висновок, щзо база для зовнішнього вимірювання продуктивності менеджменту повинна бути введена в процес підвищення конкурентоспроможності та підвищення соціальної відповідальності

Ключові слова: менеджмент, (менеджмент) система вимірювання продуктивності, иілісний підхід, підвищення конкурентоспроможності та соичіальної відповідальності, комериійні та громадські інститути розвитку

\section{Introduction}

The paper is aimed to the problem of external measurement of management performances. The measurement is considered in terms of the needs of public and commercial development institutions, researchers and other development actors. The basic objective is to obtain a coherent set of indicators for external analysis of the problems and processes of business development, as well as monitoring the progress of reforms and the allocation of development resources (in particular, analysis of public support for R\&D activities, subventions and loans to finance production for export from the aspect of broader socio-economic objectives - greater and more efficient production of tradable goods $>$ greater export $->$ increase in employment $\rightarrow>$ raising living standard). The presented matter is in addition to an introduction and conclusion divided into four parts.

The first part is aimed to the research of management performances indicators structure in the context of the need of external control to more efficiently support the development of the manufacturing sector of tradable goods according to the criteria of an open market economy. The applied methodological procedure is based on the: (1) results of SWOT analysis Why there was no greater success in increasing the effectiveness and efficiency of enterprises management and business ventures? and (2) hypothesis that the key to overcome the problems of low efficiency and effectiveness in enterprises management is a - striking a balance between market reforms and incentives and public interest streamlined in the processes of democratic decision-making, in order to create conditions for competitive, transparent and socio-economically acceptable allocation of public resources in the tradable goods production sector.

The focus of the second part is on the criteria and defining the principles for the methodology of measuring management performances. The basis is a holistic approach to solve this problem. This approach should stimulate the decision-making process and the behaviour of managers, which is based on a broader understanding of business outside of the political and financial framework. This approach is also the suggestion, which way and how should go the owners and management actors in the process of initiating the restructuring legislations (more precisely their implementation) and constituting a good business environment for private business and regular market operation.

In the third part is presented the author's view of the set of 23 indicators to quantify six key dimensions of the frame to measure the management performances in terms of the needs of public and commercial development institutions, researchers and other development actors (in particular, public support for R\&D activities, subventions and loans to finance production for exports). The aggregating of several indicators was identified as the key problem, indicators which measure the same or complementary dimensions of management performances.

In the fourth part is given a critical evaluation of quality and reliability of the implementation of the selected set of indicators for measuring the management efficiency. The key finding is that the framework for external measurement of management performances should be put into operation of: (1) improving the competitiveness and (2) increasing the social responsibility. And for both, the management should at the same time (synchronized) realize the: (1) better economic performances of its businesses and operations, (2) environmental protection and (3) social welfare, whereby shall not be in any way compromised, nor the rights of the owner, nor the rights of other stakeholders inside and outside the company. The conclusion is that the main barriers in the external measurement of management performances for the needs of public and commercial institutions are of cultural nature (development of the cultural pattern in which the priorities are: confidence, accuracy, giving a great importance to the work as the main source of existence of the individual and family, in terms of adequate rewarding the waiver of consump- 
tion at the present at the expense of productive investment in new jobs).

\section{Literature review}

Interest on performance measurement and management has increased in the last 25 years [1]. This topic is especially interesting for countries in transition, like Serbia, where previous research has shown that Serbia is lagging behind in quality of corporate management, especially the developed countries [2]. At the beginning, it should be noted that there is no agreement on the content of the term successful management control, and consequently even on determining an appropriate set of indicators for its measurement. In seeking solution to this problem, the key is a clear distinction between the public management system and ways of its implementation at the micro-level (corporate and entrepreneurial management) [2-4] for the quantification of six key dimensions of the frame for management performances measurement (social dimension, executive dimension, management and administrative dimension, regulatory and judicial dimension) [4-6].

\section{The structure of indicators for measuring} the management performances in the context of the needs to increase the external control efficiency

In this paper, the problem of determining the set of indicators for measuring the management performances is discussed in the context of the need to increase the efficiency of external control of the tradable goods production (within the national project of re-industrialization in the period from 2015 to $2030 / 2035$ - note by the author). In this context is selected the methodological approach in which can be singled out two aspects.
The first is based on a SWOT analysis (Table 1): Why the factors, which entered the national business scene, obtaining the status of a rapidly growing market economy after 2000 and opening to the target environment, such as:

- Clearly defined mission, vision and objectives in entrepreneurial decision-making;

- The possibility to establish continuity in the improvement of corporate governance through the development of management process and functions of capital;

- Organization in the function of establishing and elaboration of three-layer management processes in the planning, organization, management and control activities;

- Econometric support in methodically determined target states;

- Risk analysis in the financial flows for the given liquidity management;

- The increased degree of freedom in identifying the impacts and pressures of non-economic and economic factors and resources;

- Application of modern (market-oriented) techniques for preparing and evaluating the investments processes that enable growth and faster capital turnover;

- Operational and investment decisions in the management processes and stages based on multidisciplinary action;

- Precise locating the responsibility for deciding on material, financial and human resources through consultations, cooperation and co-decision making;

have not resulted in more effective management of companies and business ventures, according to the minimalist criteria - ensuring cash flow, which allows the regular servicing of all obligations while preserving the minimum (target) profit rate?

Table 1

SWOT analysis: Why is there no greater success in increasing

the efficiency of corporate management and business ventures?

\begin{tabular}{|c|c|}
\hline STRENGTHS & WEAKNESSES \\
\hline 1 & 2 \\
\hline $\begin{array}{l}\text { 1. Good natural resources and climatic condi- } \\
\text { tions for production in agriculture and food } \\
\text { industry; } \\
\text { 2. Price competitiveness of workforce for } \\
\text { unqualified jobs and qualified jobs in indus- } \\
\text { tries and low and medium technologies busi- } \\
\text { nesses (the average wages and salaries in the } \\
\text { private sector are among the lowest in the } \\
\text { target environment). } \\
\text { Note: In terms of this paper the other side } \\
\text { should be also taken into consideration, the } \\
\text { fact that the physical and economic produc- } \\
\text { tivity is very low compared to the target en- } \\
\text { vironment and because of non-application } \\
\text { (ignorance?) of modern management tech- } \\
\text { niques of business organization and person- } \\
\text { nel development; }\end{array}$ & $\begin{array}{l}\text { 1. Managerial approach dominated by voluntaristic-bureaucratic model of deci- } \\
\text { sion-making and low business ethics; } \\
\text { 2. Structuring the company organization and corporations without the applicable } \\
\text { systemic models (conglomerated structure oriented to marketing mixes and realiza- } \\
\text { tion of the objectives of owners outside the basic business portfolio (the conglom- } \\
\text { erates business portfolio usually involve the real estate trading unit, which uses the } \\
\text { other parts capital as a collateral for taking loan for operations in that market), and } \\
\text { not to create conditions for the improvement of relations with co-operators, users } \\
\text { and customers in order to improve the competitiveness); } \\
\text { 3. Frequent occurrence of low level of liquidity and solvency due to: (1) avoidance } \\
\text { of dealing with the problem of correlation between financial transactions and busi- } \\
\text { ness events, (2) bad credit investments, and (3) inability to cope with the challeng- } \\
\text { es and problems of indexed adjustments in the price of inputs and capital to the } \\
\text { general rise in prices and currency changes; } \\
\text { 4. Outdated equipment, technology and products (about } 80 \% \text { of the installed } \\
\text { equipment in the tradable goods production is produced before } 1990 \text {, and the rate } \\
\text { of new products introduction in the period after } 2000 \text { is estimated at } 2 \text { to } 3 \% \text { of } \\
\text { assortment, of which about } 80 \% \text { is for slight (marketing) improvements to survive } \\
\text { in the (internal) market); } \\
\text { 5. The low level of capacity utilization (the official estimates are that their average } \\
\text { utilization in the real sector in } 2013 \text { was about } 40 \% \text { !); } \\
6 \text {. Small and underdeveloped market of inputs (small and poor quality offer of } \\
\text { inputs from the domestic market at relatively high prices and long delivery times } \\
\text { compared to foreign competition); }\end{array}$ \\
\hline
\end{tabular}


Continuation of Table 1

\begin{tabular}{|l|l|}
\hline 1 & \multicolumn{1}{|c|}{2} \\
\hline & $\begin{array}{l}\text { 7. The low level of raw material and energy efficiency technologies, processes and } \\
\text { products (surveyor, including the vision of appropriate companies management, } \\
\text { indicate that the consumption of raw materials and energy per unit of product is } \\
10 \% \text { to } 30 \% \text {, and in some cases - up to } 100 \% \text { higher compared to the relevant } \\
\text { (foreign) competition); } \\
\text { 8. The mismatch between the knowledge and skills of managers and expert teams } \\
\text { in enterprises and environmental challenges, particularly in the field to use the } \\
\text { opportunities and solving problems, which impose: (1) needs for the globalization } \\
\text { of business activities, (2) transition of the global production system, (3) inclusion } \\
\text { of companies in the more intensive use of technological progress results and (4) } \\
\text { emergence and strengthening of hyper-competition; } \\
\text { 9. The lack of investment in the development and implementation of business and } \\
\text { technological innovations, due to the avoidance of initiating and implementing the } \\
\text { projects of making profit from more dynamic, long-term and broader technological, } \\
\text { organizational and economic changes and processes; }\end{array}$ \\
\hline
\end{tabular}

\section{CHANCES - OPORTUNITIES}

1. Exploiting the positions between markets with different structures of production and consumption, which creates space for the introduction of a variety of finishing and assembly production and increase economies of scale, which would result in: (1) reduction of production costs and (2) profitability increase;

2. Exploiting the effects of preparation of Serbia for European integration. The key areas for the topic of this paper are: (1) reducing the costs of access to external markets, due to the inclusion in international transport and energy corridors, (2) more accurate and clear system of standardization and branding in order to strengthen position in the external markets and cost management, (3) increasing the efficiency of the judicial system to protect property rights and contracts, (4) more accurate and clearer criteria for promotion of national, regional, subregional and local business and investment environment;

Note: Each of these factors has the other negative side, that is, represent a threat to the survival of the company. Without going into a broader elaboration, the market and, in particular, the financial position of a significant number of companies, particularly in the sector of tradable goods production in the CEEC-10 Member States and in the Republic of Croatia as the 28th EU member state (but also in Greece, Portugal and Spain) indicates that the process of preparation for European integrations has not produced an adequate effects on improvement of business and management efficiency, but on the contrary, caused the shut down of entire industries and jobs, without replacement with new ones.

The second aspect relates to the objective of this paper - the measurement of the management performances considers, first of all, in terms of the needs of public and commercial development institutions, researchers and other actors of development, in order to increase the effectiveness and efficiency of external analysis of problems and processes of business development, as well as monitoring the progress of reforms and the allocation of development resources (in particular, public support for

\section{DANGERS - THREATS}

profitability of existing productions (due to the orientation on the production of primary and low-techs products with a little participation of the newly cre-

2. Slow and uneven recovery of demand in target sales markets (Internal market, Common market (European Union), Russia);

3. Small opportunities for rational external (co)financing of investment projects, because of bank-centric financial system oriented towards lending to non-tradable times higher than the EU average, except that after 2010 was present the tendency of their reduction!) are practically from the beginning of 2002, when began the penetration of foreign banks into the internal financial market, larger than the average profit rates in the tradable goods production); oriented coalition on the allocation of public funds, newly created value and natrepreneurship. Consequences: (1) reducing and weakening the market relations and encouraging the development of non-market impacts and pressures on companies and, in particular, publicly owned corporations, (2) vagueness of economic impacts and goals of rational voters from public elections, (3) orientation to shortterm monetary and fiscal measures and demand without substantial structural reforms and (4) growth of external deficit and unsustainable borrowing;

5. Incompatibility and avoidance of public, corporate and market regulation integrativity. Consequences: (1) centralized, unclear and non-transparent decisionmaking on the allocation and expenditure of public funds for encouraging and directing the development flow and construction, revitalization and maintenance of physical infrastructure, (2) spontaneous and short-term operations on the cyclical and long-term financial and economic crisis, (3) inadequate anti-monopoly regulation and, the key to the current situation, (4) privatization of capital without structuring and target determination of capital of functions;

6. State of the labor market, experts market and managers market and relevant segments of education system. The market of experts and managers practically does not exist. The current state of the labor market does not threaten the survival of the company in the market. However, the demographic indicators and poor education and health systems suggest that the workforce will represent a substantial development barrier after 2020, especially if on the level of national companies come to life the (average) European business and financial standards:
R\&D activities, subventions and loans to finance production for export). In this context, the initial orientation (hypothesis) is that should provide a balance between market reforms and incentives and public interest (increase the export and employment, environmental protection, ...) shaped in the process of democratic decisionmaking, in order to create conditions for a competitive, transparent and socio-economically acceptable allocation of public resources in the tradable goods production. In 
this context, it is necessary to say something about the key elements of the current transformation of the role of public factors in the formation of general frameworks for the development and their implications for the determination of indicators for measuring the management performances (the presented matter is processed according to [5]).

The Republic of Serbia is for more than a decade in the stage of constituting the conditions for the transfer of rights and responsibilities for the allocation of resources from the state to the market or the private sector, but also to other social institutions, which have emerged in this period. This particularly applies to the so-called non-governmental organizations and other forms of civil society, and the promotion of neo-liberal system of values, as the basic socio-economic orientation. Technically, this approach is marked by: (1) market liberalization, (2) increase of the degree of freedom of movement of capital, and (3) development of economic and legal institutions aimed at stimulating and maintaining (1) and (2). After more than a decade of implementation, it is more evident that the discretionary role of the government in the allocation of resources can be reduced, if only as a substitute introduce clear, precise and transparent principles based on some aspects of reforms and management actions in which in the forefront are the rights and not the needs (Table 2).

Table 2

The implications of the concept of rights for companies management behaviour

\begin{tabular}{|c|c|}
\hline $\begin{array}{l}\text { Manager s behaviour when the public regulation struc- } \\
\text { ture is dominated by the concept: needs }\end{array}$ & $\begin{array}{l}\text { Managers behaviour when the public regulation structure is } \\
\text { dominated by the concept: rights }\end{array}$ \\
\hline The needs are met. & The right is exercised. \\
\hline The needs do not imply any commitment. & $\begin{array}{l}\text { The acquisition of rights implies corresponding duties and } \\
\text { responsibilities. }\end{array}$ \\
\hline The needs are not universal. & $\begin{array}{l}\text { The rights are universal. } \\
\end{array}$ \\
\hline $\begin{array}{l}\text { The needs can be met in a variety of ways, on condi- } \\
\text { tion that some desired set of results are achieved (for } \\
\text { example, a minimum quantity or financial resources to } \\
\text { each user). }\end{array}$ & $\begin{array}{l}\text { The needs can be achieved on condition that the process and } \\
\text { results are simultaneously respected. }\end{array}$ \\
\hline $\begin{array}{c}\text { The needs can be ranked in order of priority } \\
\text { (for example, privileged industries, companies and } \\
\text { businesses, etc.). }\end{array}$ & $\begin{array}{l}\text { The right is indivisible and must be achieved in full and at the } \\
\text { same time (of course, in normal conditions - without war, } \\
\text { catastrophes, disasters and the like by clearly defined and } \\
\text { transparent commercial terms). }\end{array}$ \\
\hline $\begin{array}{l}\text { The needs can be achieved in various ways: by gifts, } \\
\text { donations, subventions, through the aid, awarding a } \\
\text { discretionary to the full or partial write-off of claims } \\
\text { from suppliers and the like. }\end{array}$ & $\begin{array}{l}\text { In normal conditions, gifts, donations, subventions, aid, } \\
\text { awarding a discretionary to various write-offs are incompati- } \\
\text { ble with the rights-based approach (this means that all eco- } \\
\text { nomic entities and the population must regularly meet their } \\
\text { obligations, the only exception are the individuals unable to } \\
\text { work - which is in the domain of social policy } \\
\text { in the narrow sense). }\end{array}$ \\
\hline
\end{tabular}

The presented indicates that the application of the concept of human rights, or economic entities, is based on the completion of institutions and norms that will allow everyone to take a responsibility for meeting ones needs and their development in the future. On the technical side, it can be seen - that the development does not go from the state top to the individual (in this case company and its management - note by the author, but vice versa, the development is a process that goes from the individual in terms of people and their families, or economic entities and their associations to the state (the so-called holistic approach, about which will be discussed in the next paragraph). At this point should be stated that the process of adopting this approach is initiated in modern market economies at the beginning of the last decade of the last century (the European Union with delay of almost a decade on the basis of this development paradigm formulated and tried to implement a Common strategy of re-industrialization of the EU, the so-called Lisbon Agenda of March 2000)), but it is very difficult and slow to operationalize, which is indicated by the appearance of the first and second waves of (current) global financial and economic crisis, and the fact that the modern market economies very slowly and unevenly recovery from their consequences.

\section{Principles for the methodology of measuring the management performances}

The solution to successful management control and measuring of management performances is determining the adequate combination of measurements of objectives realization in the field of: increasing economic performances (companies and businesses within the open market economy), protection and improvement of the environment and social welfare, and on the other hand, in meeting the expectations of owners and all other interest groups in and outside of company. The key to implement this approach is a holistic view of business enterprises (Frame 1). This approach should stimulate the decision-making process and the behaviour of company management, which is based on a broader understanding of business outside of the political and financial framework. This approach is also the suggestion, which way and how should go the private business actors in the process of legislation restructuring initiation and constitution of good business environment for private business and regular market operations. A good entrepreneur and manager must very care- 
fully and systematized submit the proposals, comments, criticisms and statements of support to their environment, to his work on management will be sufficiently supported and less distracted on aside. At the same time must do it in a way which will make the co-workers cooperative, rather than disinterested or competitive

Frame 1

Holistic approach in determining the good public and corporate governance in gas industry

The holistic approach has two characteristics. The first is that defining the key (may be called the ultimate) development goals should be lowered to the executive level. The second, individual goals are adjusted starting from the different observation perspectives. The implementation of the holistic approach relies on a network of public, corporate and entrepreneurial policies and strategies composed of four nodes, representing four different views of this problem. The first node is macro-management. Its ultimate goals are to: (1) increase the standard of living, above all, by reducing the unemployment by increasing the productive employment, (2) improve the conditions for development privatization in function to increase export and newly created value, (3) increase the fiscal revenue. The second node is microeconomic management. Its ultimate goals are to: (4) increase the profit, (5) improve the investment capacities, (6) reduce the conflicts because of market power disproportion between the public regulation actors and competitive industries. The third node includes institutions and regulation. This structure forms a commercial and public part. The top of the commercial part form: (a) a congregation of banks, which ultimate goals are: (6) short term investments, (7) high interest rates and (8) low risks. The public part form: (b) monopoly control, (c) disputes resolution; (d) set of local, subregional, regional, national and European plans, norms and standards. Its ultimate goal is: (9) Respect for consumer and environmental standards. The fourth node forms a system of values. Its ultimate goals are: (10) prevention of corruption and (11) respect for economic freedoms.

In the case of the Republic of Serbia, the measurement of management economic performance should be inferred directly from the regular servicing of all obligations of their companies and mass and profit structure in comparison with analogous indicators in closer and wider international environment. Since these are known techniques, the focus of this part of paper is on the selection of principles for measuring the realization of other objectives. The suggestion is indirect measurement of management performances using indicators classified into three groups $[2,3,6,7]$ :

The first includes the inputs or input values. The bases are: laws, certain specific rights, accepted domestic and international obligations and the like. The indicators for measuring are the facts derived from the analysis of relevant laws, contracts and agreements, accepted obligations. These indicators are the basis for de jure concept of determining the content of concept successful management control, but do not show - "What is the real situation?" Or "What happens: on the level of the enterprise?"

The second includes the processes or procedures which lead to the realization of the adopted laws and rights, acceptance of contracts and the obligations and the like. These indicators determine where is the company on the way from the adopted laws and accepted contracts, agreements and commitments to their realization. Although this is a de facto concept of the term: a successful management control, there is no information on the achievement of concrete results, implementation of specific rights and the like.

The third includes outputs, outcomes, results or actual performances. The measure is - "How many companies, but also how many people and their families enjoy the fruits of the adopted laws, agreements, contracts and the like, and at what price?"

Before the concretization of the set of indicators to measure the performance, it is necessary to say something about the method of principles for their choice. The criteria for determining the indicators are derived from the Universal Declaration of Human Rights of 1948 and the Vienna Declaration on Human Rights of 1993. The Republic of Serbia is a signatory of both documents, but - "What does that have to do with successful management control in export industries, companies and businesses?" Extracting their essence, this can be summarized in six general principles:

First, the principle of participation, that is, respecting the genuine interests in the triangle: state (in terms of the holder of the public interest) - company internal and external stake-holders;

Second, the principle of equality, that is, its application in the formation of rules wherewith the rights and interests of all participants in the chain of reproduction are entirely respects;

Third, the principle of egalitarianism, that is, in the application of rules to everyone, regardless of income, economic, political and social status;

Fourth, the principle of responsibility, that is, all the elected actors must be responsible for own activity and respect the justified demands of the state and the internal and external stake-holders;

Fifth, the principle of transparency, that is, the decision-making process must be effective, clear, transparent and open to review by the state and the internal and external stake-holders;

Sixth, the principle of efficiency, that is, exactness of rules of the game, which allow quick and timely decision-making;

leads to solutions which suggest ways to go in overcoming the crisis of development of export industries, companies and businesses.

\footnotetext{
5. Review of indicators and problems of their implementation in measuring the management performances

Based on the listed principles and available literature [4-9] is designed a coherent system composed of 23 indicators for the quantification of six key dimensions of the frame for management performances measurement from the aspect of the needs of public and commercial development institutions, researchers and other development actors (in particular, public support to R\&D activities, subventions and loans to finance production for export):
} 
Table 3

Indicators for the quantification of key dimensions of the frame for management performances measurement

\begin{tabular}{|c|c|c|}
\hline $\begin{array}{l}\text { The dimension of } \\
\text { problem: }\end{array}$ & & Performances measurement indicator: \\
\hline \multirow[t]{5}{*}{ Social dimension: } & 1 & $\begin{array}{l}\text { The freedom of public opinion and expression on the activities of state and private sector in export } \\
\text { industries, companies and businesses. }\end{array}$ \\
\hline & 2 & The freedom of business entities association. \\
\hline & 3 & The prohibition of discrimination by the state and other economic entities. \\
\hline & 4 & $\begin{array}{l}\text { The possibility of public debate on lows, agreements and contracts and all other matters related to } \\
\text { the issue of development of export industries, companies and businesses. }\end{array}$ \\
\hline & 5 & $\begin{array}{l}\text { The respect for rules and laws in the triangle state (in terms of the public interest holder) - compa- } \\
\text { ny management - internal and external stake-holders. }\end{array}$ \\
\hline \multirow[t]{3}{*}{ Integrative dimension: } & 6 & $\begin{array}{l}\text { The expression of public interest in the development, technological and economic policies for the } \\
\text { needs of export industries, companies and businesses. }\end{array}$ \\
\hline & 7 & $\begin{array}{l}\text { The role of legislature in determining the goals and actions of public policies in export industries, } \\
\text { companies and businesses. }\end{array}$ \\
\hline & 8 & $\begin{array}{l}\text { The responsibility of elected or appointed officials in determining the goals and actions of public } \\
\text { policies and their implementation in the export industries, companies and businesses. }\end{array}$ \\
\hline Executive & 9 & The right to security. \\
\hline \multirow[t]{2}{*}{ dimension: } & 10 & The right to work and life. \\
\hline & 11 & $\begin{array}{l}\text { The willingness to take tough decisions - as opposed to opportunism and easing the current and } \\
\text { populist demands. }\end{array}$ \\
\hline \multirow[t]{5}{*}{$\begin{array}{l}\text { Managerial and ad- } \\
\text { ministrative dimen- } \\
\text { sion: }\end{array}$} & 12 & $\begin{array}{l}\text { The degree of influence of advice of experienced officials, experts and enterprise managers to } \\
\text { formulate the content of public policies, decisions and their implementation. }\end{array}$ \\
\hline & 13 & $\begin{array}{l}\text { The extent to which expertise and results affect employment and career development of officials, } \\
\text { experts and companies managers. }\end{array}$ \\
\hline & 14 & $\begin{array}{l}\text { The responsibility of officials, experts and companies managers - providing the independent con- } \\
\text { trol and audit and legal responsibility. }\end{array}$ \\
\hline & 15 & $\begin{array}{l}\text { Transparency - free access to documents and rules on the basis of which are made a public deci- } \\
\text { sions in the triangle: state (in terms of the public interest holder) - company management - internal } \\
\text { and external stake-holders. }\end{array}$ \\
\hline & 16. & $\begin{array}{l}\text { Equality in free access to use public goods and services of public administration intended to sup- } \\
\text { port the export business development. }\end{array}$ \\
\hline \multirow[t]{4}{*}{ Regulatory dimension: } & 17 & $\begin{array}{l}\text { Equal treatment of all participants in the triangle: state (in terms of the public interest holder) - } \\
\text { company management - internal and external stake-holders. }\end{array}$ \\
\hline & 18 & $\begin{array}{l}\text { Conditions for the opening of new enterprises and businesses - the complexity of process, the } \\
\text { number of permits, required time and costs. }\end{array}$ \\
\hline & 19 & $\begin{array}{l}\text { Consideration of international political and economic conditions in programming the development } \\
\text { of export industries, companies and businesses. }\end{array}$ \\
\hline & 20 & Consultation with users and private sector in the process of making public policies. \\
\hline Judicial & 21 & Respecting the legal procedures. \\
\hline \multirow[t]{2}{*}{ dimension: } & 22 & The responsibility of judges. \\
\hline & 23 & $\begin{array}{l}\text { The ability to solve conflicts in the triangle: state (in terms of the public interest holder) - compa- } \\
\text { ny management - internal and external stake-holders. }\end{array}$ \\
\hline
\end{tabular}

The nature of the proposed indicators suggest that some are based on primary data sources (such as the analysis of: texts of laws, contracts and agreements), surveys and interviews (where should distinguish the domestic or internal evaluations of residents from external or foreign evaluations of non-residents - foreign representatives, analysts, diplomats, etc.). For others it is necessary to combine the primary sources with secondary sources (for example, with information obtained by similar studies in other countries), to ensure adequate coverage of some harder measurable dimensions of quality of management control. Even more difficult is the problem: "What is the minimum and what is the maximum in evaluating the management performances? and consequently, establishment of rules to guide the various public and commercial development institutions in assigning the subventions, loans and providing technical support. In any case, the common in the present approach is the problem of aggregating several indicators, which meas- ure the same or complementary dimension of management performances.

\section{Discussion. The quality and reliability of im-} plementation of the proposed framework for measuring the management performances

Considering that the proposed framework for measuring performances is determined in accordance with the orientation that on the level of corporate governance is necessary to open a space for re-industrialization strategy in accordance with the criteria of the target environment (the European concept of endogenous, autopropulsive and self-sustainable economic, social, ecological and cultural development - note by the author), the question is: "How much is this possible and which instruments to use?" The problem has more dimensions so the elaboration will be limited to the improvement of: (1) competitiveness and (2) social responsibilities in management control. 
In accordance with neo-liberal paradigms, the role of management in improvement of competitiveness of (their) companies and businesses in the modern market economies is linked to the solution of so-called agency problem or to the improvements of mechanisms of public regulation of business activities. There are two approaches. The first is reduced to a threat to managers that they will be fired if they do not act in accordance with the interests of owners. In the literature, the main emphasis is on the mismatch between the effects of control of managerial behaviour, control costs and (owners) willingness to settle those costs. The second is the creation of incentive schemes for managers. From the aspect of the objectives of this paper, solutions for the effective management control in function should be sought primarily in the mechanisms for strengthening the social responsibility.

Its content is determined as the micro-contribution of each enterprises to the sustainable national (economic, social, ecological and cultural) development, that is, as an approach in which the company management strives to simultaneously achieve: (1) increasing the economic performance of own company and businesses, (2) environmental protection, and (3) social welfare, whereby will not be compromised nor the rights of the owners nor the rights of other interest groups inside and outside the company. The instruments for the realization of such a complex goals can be classified into four groups [7]:

First, principles and instructions. The companies should introduce appropriate formalized reports, which would make available to public at least once a year.

Second, supervisory control and standards. In improvement of performances the international standards have a crucial role, such as: (1) Quality Management System (ISO 9000), (2) Environmental Management System (ISO 14000), (3) Social Accountability System (SA 8000), (4) Health and Safety Management System (OHSA 18000) and the like. Each of the listed standards covers a narrower or broader set of enterprise activities which as the ultimate result have the respect of legislation and obligations toward all relevant interest groups, as well as the achievement of specific goals.

Third, benchmarks and reports. The companies must be more transparent and precise in (annual) reporting to the public. And, in this area circulate standard instruments such as: (1) Sustainability and Corporative Social Responsibility (CSR) Reporting - Global Reporting Initiative (GRI), (2) Corporate Sustainability Reporting Toolkit, (3) CSR Assessment Tool and the like.

Fourth, other instruments. Their application is based on the need to: (1) integrate the corporate social securities objectives in corporate structures and processes, (2) create innovative solutions, (3) intensify cooperation with internal and external groups, and (4) more accurate reporting on achievements and problems. The key instruments are: (1) awards, (2) education and training, (3) partnerships and (4) promotion and communication.

In studying the problem of constitution and application of framework for measuring the management performance according to this concept, two things should be observed. The first is that its constitution and application is, primarily, a matter of human creation, that is, its essence is in understanding the risks behind every (com- mercial and public) decision. For more successful solving of this problem it is necessary in the selection of actors of industrial, financial and political system to give a greater significance to possession and use of: (1) specific knowledge and skills, (2) ability to reliably understand the problem and coping with complex and uncertain environment, and (3) specific ability to create solutions and persistence in their realization.

The second is that there are circumstances in which there are no conditions for the application of any scientifically valid concept for measuring the management performances. Simply, there are socio-economic systems in which there are a little successful management results. This problem in the case of the Republic of Serbia has several dimensions, but here will be elaborated the problem: What is blocking the development of the cultural pattern in which the priorities are: confidence, accuracy, giving a great importance to work as a main source of existence of the individual and family, in terms of adequate rewarding the waiver of consumption in the present at the expense of productive investment in new businesses?

At the beginning, the consideration of causes that block the development of a positive management culture will be put into the context of the evaluation of effectiveness and efficiency of the socio-economic framework to encourage restructuring and development of export industries, companies and businesses. Precisely in this area is a little real results, because the performed reforms and policies resulted in the disappearance of most export industries, primarily in the electro-metal complex, complex for performance of investment operations abroad and complex for the production of consumer goods. Even more fatal is that the Republic of Serbia has very little (internal) private initiatives for the development of export enterprises and businesses. The experiences from the period from 2001 to 2013, show that even the implementation of institutional reforms modelled on the European Union and other international economic and political organizations with an emphasis on gaining trust of foreign investors has not led to an explosive growth of external financing of development programs, since it was shown that the servicing of imports of goods from highly developed countries for foreign capital is more attractive, and certainly less risky alternative than investing in the development of export industries, companies and businesses.

In my opinion, the key reason that blocks the development of positive management culture is the domination of distributive-oriented coalitions (Frame 2). There is no doubt that the Republic of Serbia is full of distributiveoriented coalitions, which in the shape of a pyramid covers all levels of their socio-economic beings. Let's start from the fact that, undoubtedly, the ruling parties are the key distributional-oriented coalitions. Such orientation is manifested in party affiliation as a sole criterion for performance of influential businesses in economy and practically all businesses in the public (and partly in private) sector. This phenomenon is on the principle of concentric circles spread to such an extent that practically all resources, powers and political powers are aimed at the distribution of existing. Of course all distributive-oriented coalition 
does not have the same power in the appropriation of new value and inherited (social) wealth. Those at the top are the most powerful and most ruthless. At every next level of socio-economic organizations are, similarly to hierarchical bureaucratic system, other distributive-oriented coalitions which serve to politically and in every other way justify or conceal those at a higher level. Of course, the management of almost all companies is included in the appropriate distributive-oriented coalitions, because the affiliation to appropriate is the basic condition for unsanctioned tax evasion and business in transition zone between the official and the "gray" economy.

What are the distributive-oriented coalitions?

Frame 2

The concept of distributive-oriented coalition means special interest groups which by merging provide improvement of their posi-
tion in the distribution of added value and social wealth without adequate personal contribution to their maintaining or increasing.
The main socio-economic characteristics of distributive-oriented coalitions are: (1) tendency towards the development of monop-
oly political, social and economic structures, (2) weakening of interest in adaptation to social, economic and cultural changes in
environment, (3) tendency toward (ab)use of administrative-hierarchical instead of market mechanisms of evaluation and alloca-
tion, and (4) tendency toward encouraging the development of distributive-oriented coalitions at lower levels of socio-economic
organization, in order to hide the true intentions of actors of special interest key groups.
The causes and consequences of the development and operation of a distributive-oriented coalition in Serbia see, for example, in
Adžić, S. Popović, D. (2005), Fiskalni sistem i fiskalna politika - njihov doprinos unapređenju konkurentnosti privrede: Slučaj
Srbije, "Ekonomija/Economics", No 1, pp. 173-200. (The fiscal system and fiscal policy - their contribution to improving the
competitiveness of economy: The case of Serbia)

One of the most serious consequences is the state of value system. Its main characteristic is that the culture of ability to grab by all means is more appreciated and respected than the ability to create new values and wealth. Accordingly, a radical change are made in the total life commitments, from the fall of interest in learning and professions directed towards the production and growth of tendencies towards professions engaged in the distribution of what has been created, as well as "inflation" of diplomas (especially in the higher education system!), to the level rejecting any commitments with regard to positive results of work and successful businesses finalization. Thus the work, creativity and confidence, which were not (ever) highly ranked in the hierarchy of value systems, replaced by model of solving the key business and life problems through: speculation, evasion of fiscal obligations, frauds, kidnappings, crime and so on. Of course, in such a value system is illusory to talk about the need for hard work on development and promotion of international competence of individuals and the competitiveness of any socio-economic unit, from business or public function (services), through the company, and to the state.

\section{Conclusion}

The necessary conditions to constitute a framework for measuring the management performances in the context of the need of external control to more efficiently support the development of the tradable goods manufacturing sector according to the criteria of an open market economy are in poor condition. However, its constitution and application are not determined by fate as unachievable. It is necessary to identify all the main obstacles and deficiencies and deliberately eliminate them. Three operational conclusions can be performed:

First, the presented concept of operationalization the framework for measuring the management performances is based on systematic integration of paradigms: learning and cooperative cooperation, induced from the mass and, mostly, informal communication between individuals, economic and non-economic entities on the basis of the information flow and exchange of experiences nec- essary for prompt and (economically) effective action for the operationalization of individual and group preferences in conditions of sharp, open and unfair competition.

Second, the basic condition for the application of scientifically valid concept for measuring the efficiency of management is the elimination of excessive influence of distributive-oriented coalitions.

Third, the operationalization of the proposed concept should be, due to the state of general institutional disorder, organized step by step. The first is certainly the promotion of more efficient models of regulation of relationships, behaviours and their monitoring and evaluation to which in the forefront are the permanent efforts for more accurate and more transparent evaluation of results of public intervention in terms of increasing the competitiveness of industries, companies and businesses and promoting the advancing social responsibility.

\section{References}

1. Taticchi, P. Forward performance measurement and management integrated frameworks [Text] / P. Taticchi, K. R. Balachandran // International Journal of Accounting \& Information Management. - 2008. - Vol. 16, Issue 2. P. 140-154. doi: 10.1108/18347640810913807

2. Begović, B. Unapređenje korporativnog upravljanja [Text] / B. Begović et. al. // Beograd Centar za liberalnodemokratske studije, 2003.

3. Begović, B. Korporativno upravljanje: Pet godina kasnije [Text] / B. Begović et. al. // Centar za liberalnodemokratske studije, Beograd, 2008.

4. Taticchi, P. Performance measurement and management: a literature review and a research agenda [Text] / P. Taticchi, F. Tonelli, L. Cagnazzo // Meas Bus Excell. -2010. Vol. 14, Issue 1. - P. 4-18. doi: 10.1108/13683041011027418

5. Hyden, G. Governance and Development [Text] : world governance survey discussion paper 1 / G. Hyden, J. Court. - Union Nations University, Tokyo, 2002.

6. Sjostrom, E. Investment Stewardship: Actors and Nethods for Socially and Environmentally responsible investments [Text] / E. Sjostrom. - Project Report for the Nordic Partnerships, School of Economics, Stockholm, 2004.

7. Kaufmann, D. Governance Matters V: Aggregate and Individual Governance Indicators for 1996-2004 [Text] / D. Kaufmann, A. Kraay, M. Mastruzzi. - World Bank Policy Research Department Working Paper, 2006 
8. Lončar, D. Korporativna socijalna odgovornost: koncept, rejting, instrumenti i značaj, Zbornik radova: "Miločerski ekonomski forum 2007: Korporativno i javno upravljanje u funkciji razvoja konkurentnosti" [Text] / D. Lončar // Savez ekonomista Srbije i Savez ekonomista Crne Gore, Beograd, 2007. - P. 358-376.

9. Vujović, D. Pojava kompozitnih indikatora upravljanja: potreba ili globalna moda bez povoda, Zbornik radova: "Miločerski ekonomski forum 2007: Korporativno i javno upravljanje u funkciji razvoja konkurentnosti" [Text] / D. Vujović // Savez ekonomista Srbije i Savez ekonomista Crne Gore, Beograd, 2007. - P. 209-232.

\section{References}

1. Taticchi, P., Balachandran, K. R. (2008). Forward performance measurement and management integrated frameworks. Int J Acc \& Info Management, 16 (2), 140-154. doi: $10.1108 / 18347640810913807$

2. Begović, B. et. al. (2003). Unapređenje korporativnog upravljanja. Beograd Centar za liberalno-demokratske studije.

3. Begović, B. et. al. (2008). Korporativno upravljanje: Pet godina kasnije, Centar za liberalno-demokratske studije, Beograd.

4. Taticchi, P., Tonelli, F., Cagnazzo, L. (2010). Performance measurement and management: a literature review and a research agenda. Measuring Business Excellence, 14 (1), 4-18. doi: 10.1108/13683041011027418

5. Hyden, G. and Court, J. (2002). Governance and Development. World Governance Survey Discussion Paper 1, Union Nations University, Tokyo.

6. Sjostrom, E. (2004). Investment Stewardship: Actors and Nethods for Socially and Environmentally responsible investments, Project Report for the Nordic Partnerships, School of Economics, Stockholm.

7. Kaufmann, D., Kraay, A., Mastruzzi, M. (2006). Governance Matters V: Aggregate and Individual Governance Indicators for 1996-2004. World Bank Policy Research Department Working Paper.

8. Lončar, D. (2007). Korporativna socijalna odgovornost: koncept, rejting, instrumenti i značaj, Zbornik radova: "Miločerski ekonomski forum 2007: Korporativno i javno upravljanje u funkciji razvoja konkurentnosti", Savez ekonomista Srbije i Savez ekonomista Crne Gore, Beograd, 358-376.

9. Vujović, D. (2007). Pojava kompozitnih indikatora upravljanja: potreba ili globalna moda bez povoda, Zbornik radova: "Miločerski ekonomski forum 2007: Korporativno i javno upravljanje u funkciji razvoja konkurentnosti”, Savez ekonomista Srbije i Savez ekonomista Crne Gore, Beograd, 209-232.

Дата надходженнярукопису 22.06.2015

Sofija Adzic, Professor, Faculty of Economics, University of Novi Sad, Segedinski put 9-11, 24000 Subotica E-mail: sofijaa@ef.uns.ac.rs

УДК 330.42

DOI: $10.15587 / 2313-8416.2015 .46586$

\title{
РОЗРОБКА МЕТОДІВ ДЛЯ ВИЗНАЧЕННЯ РАЦІОНАЛЬНИХ СТРАТЕГІЙ РОЗВИТКУ ЕНЕРГЕТИЧНОЇ ПРОМИСЛОВОСТІ
}

\author{
(C) М. А. Острочрева, К. О. Ільченко
}

У роботі досліджується питання розвитку енергетики Украӥни иляхом впровадження кількісного очінювання за допомогою інтегрального показника. Він демонструє мінімізацію розходжень наявних основних показників діяльності теплових електростанцій Украӥні від нормативних значень, щзо регламентуються документами ЄС у рамках підписання Угоди про асоиіаџію між Україною та ЄС

Ключові слова: теплоелектростанція, інтегральний показник, енергетична безпека, нормативні значення, енергоефективність, екологічна безпека

The development of energetic field of Ukraine by implementing quantitative assessment with using the integral index is researched in this work. It demonstrates minimize differences existing key performance indicators of thermal power plants Ukraine from normative values that governed by documents of EU within the Association Agreement between Ukraine and the EU

Keywords: power plant, integral index, energy security, normative values, energy efficiency, environmental safety

\section{1. Вступ}

Донедавна питанню енергетичної безпеки України не надавалося належної уваги. Тому історично склалися передумови до відсутності диверсифікації постачальників паливних ресурсів, наявності великої кількості застарілого обладнання, низької ефективності електростанцій, великих втрат та високих цін за електроенергію.

Наразі, враховуючи підписання Угоди про асоціацію з СС та очікуваний перехід на європейські стандарти, необхідно привести у відповідність енер- гетичну систему країни 3 точки зору норм безпеки та міжнародних стандартів.

\section{2. Постановка проблеми}

Об’єктивні тенденції розвитку економіки перетворили енергетичну сферу на один із провідних пріоритетів як світової, так і регіональної політики. Ця сфера виступає одним 3 основних напрямків співробітництва України з СС, що грунтується на взаємозалежності та спільних інтересах, і підкріплюється стратегічним курсом України на повноцінну інтеграцію до ЄС [1]. 